\title{
КОРЕЛЯЦІЙНИЙ ПІДХІД ДО ОБҐРУНТУВАННЯ ОПТИМАЛЬНИХ МОДЕЛЕЙ РОЗГАЛУЖЕННЯ МІКРОСУДИННИХ ВУЗЛІВ
}

\author{
В. П. Марценюк, Д. В. Вакуленко, І. Є. Андрущак \\ Тернопільський Аержавний медичний університет імені І. Я. Горбачевського \\ e-mail: $\underline{\text { dmitro v@ukr.net }}$
}

\begin{abstract}
В роботі проведено огляд в галузі оптимальності судинної архітектоніки. Запропонована математична модель біфуркацій судин, перевірена на доступних нам результатах дослідження. Отримані значення ј" та ј* корелювали зі значеннями, отриманими експериментально, коефіцієнт кореляції був більший 0,93, що свідчить про адекватність запропонованої моделі. Модель розрахунку кутів розгалуження судин діаметром від 10 мкм до 100 мкм $€$ коректною і універсальною та доповнює правило Ру, використане в моделі Мюррея.
\end{abstract}

Ключові слова: розгалуження судин, модель, коефіцієнт кореляції

\section{КОРРЕЛЯЦИОННЫЙ ПОДХОД ДЛЯ ОБОСНОВАНИЯ ОПТИМАЛЬНЫХ МОДЕЛЕЙ РАЗВЕТВЛЕНИЯ МИКРОСОСУДИСТЫХ УЗЛОВ}

\author{
В работе проведен обзор в области оптимальности сосудистой архитектоники. Предложена математическая \\ модель бифуркаций сосудов, проверена на доступных нам результатах исследования. Полученные значения кор- \\ релировали со значениями, полученными экспериментально, коэффициент корреляции был больше 0,93, что \\ свидетельствует об адекватности предложенной модели. Модель для расчета углов разветвления сосудов диа- \\ метром от 10 мкм до 100 мкм является корректной и универсальной и дополняет правило Ру, использованное в \\ модели Мюррея.
} $\begin{aligned} & \text { В. П. Марценюк, Д. В. Вакуленко, И. Е. Андрущак } \\ & \text { Тернопольский государственный } \text { медицинский университет имени И. Я. Горбачевского }\end{aligned}$

Ключевые слова: разветвление сосудов, модель, коэффиициент корреляции

\section{CORRELATION APPROACH FOR THE SUBSTANTIATION OF OPTIMUM MODELS OF MICROVESSELS' NODES BIFURCATION}

\author{
V. P. Martsenyk, D. V. Vakulenko, I. Ye. Andrushchak \\ Ternopil State Medical University by I. Ya. Horbachevsky
}

\begin{abstract}
We conducted a survey in optimal vascular architectonics. An offered model of vascular bifurcations was tested on the study

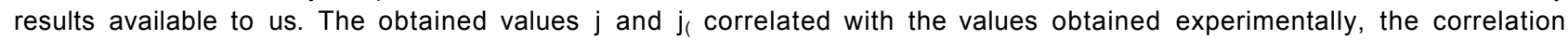
coefficient was bigger 0.93 , indicating the adequacy of the proposed model. The model of angles calculation of vessels forking with a diameter of 10 microns to 100 microns is correct and universal and normally complements Roux's rule used in the model of Murray.
\end{abstract}

Key words: fork of vessels, model, corrélation coefficient.

Вступ. Морфологія серцево-судинної системи ссавців надзвичайно складна. Загальна довжина судин дорівнює приблизно 100000 км (більшу ії частину складають капіляри). При дослідженні будови цієї системи, як на живому організмі (наприклад, на перетинці задньої лапи жаби), так і на гістологічному препараті, з першого погляду виникає враження, що неможливо висунути яку-небудь просту гіпотезу, яка дозволила б кількісно описати серцево-судинну систему. Саме через таку складність серцево-судинна система ссавців $є$ чудовою моделлю, що ілюструє ефективність застосування найпростіших методів, які спираються на принцип оптимальності в біології [1] .

При визначенні поняття розгалуження макросудин в спеціальній літературі використовують наступні терміни: "розгалуження", "біфуркація", дихотомічне

(ㄱ В. П. Марценюк, Д. В. Вакуленко, І. Є. Андрущак 
ділення (розгалуження)" (рис.1,a), "відгалуження" (рис. 1,б); "трифуркація", "трихотомічне ділення (розгалуження)" (рис.1,c); "мультифідне розгалуження" (рис.1,д); "судинний трійник" (складається 3 трьох судин - стовбура та двох гілок) [2]. Для раціонального визначення терміну розгалуження мікросудин i його повного кількісного опису в [3] запропоновано використовувати універсальний термін "мікросудиннй вузол", який може бути застосований для будь якого виду розгалужень. Мікросудиннй вузол характеризується ступенем розгалуження, який дорівнює числу мікросудин, що його утворюють.

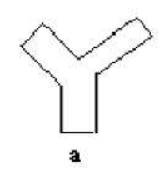

F

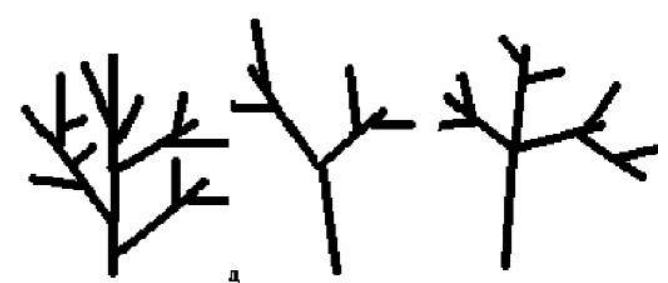

Puc. 1. Види розгалуження мікросудин.

Мікросудинний вузол виконує функцію локального розподілу мікропотоків крові. 3 біомікроскопічних спостережень відомо, що в мікросудині може відбутися зміна напрямку потоку крові на протилежний, а також тимчасова зупинка крові [4].

До цього часу не було зроблено якісної та кількісної оцінки судинного розгалуження для судин різних типів та діаметрів.

Мета дослідження. Здійснити огляд результатів в галузі оптимальності судинної архітектоніки, запропонувати спрощену модель біфуркації судин на основі принципу оптимальності.

Основна частина. Вперше проблема функціональної анатомії судинних розгалужень була сформульована в 1878 році Roux W. [5], він встановив зв'язок між величиною кута розгалуження артеріальної біфуркації та діаметрами просвітів материнського стовбура і його дочірніх гілок. Виявлені закономірності конфігурацій артеріальних біфуркацій були сформульовані у вигляді так званих правил Ру $[6,7]$.

Для пояснення цих правил запропонована гіпотеза, 3 якої випливає, що конструкція та функціонування серцево-судинної системи відповідає принципу мінімальних затрат біологічного матеріалу, витраченого на їі побудову, і принципу мінімальної роботи, необхідної для переміщення по ній крові. При цьому артеріальні біфуркації під впливом гемодинамічного фактора набувають конфігурацій, котрі для даних умов є оптимальними.

Англійський фізіолог Murray C. D. в 1926 році [8] для аналізу конфігурації судинної біфуркації вперше запропонував оціночну функцію. Модель Мюррея дозволила кількісно пояснити емпіричне правило Ру [6]. Експериментальна перевірка цієї моделі для біфуркацій піальних артерій [9], утворенних судинами 3 діаметром внутрішнього просвіту менше 100 мкм, показала, що теоретично передбаченні величини оптимальних кутів між дочірніми гілками в розгалуженні не збігаються 3 їх реальними значеннями. Виявилось, що правила Ру виконуються тільки для біфуркацій судин діаметром більше 100 мкм. Для біфуркацій судин 3 діаметрами просвіту менше 100 мкм модель Мюррея не працює, i, відповідно, правила Ру не виконуються (межа 100 мкм має наближене значення та умовний характер). В [1] запропоновано модель для розрахунку кутів розгалуження судин на основі принципу оптимальності.

Кількісні математичні моделі в архітектоніки судин нирок поодиноких [10-13] та парних нефронів описано в $[14,15]$. Ці моделі непогано відтворюють такі характеристики, як частота коливань та рівні максимального та мінімального тиску в проксимальному канальці.

Побудова моделі. Виходячи з принципу оптимальності можна розв'язати проблему визначення кута розгалуження судин. Припустимо, що $R_{T}$ - повний опір ділянки $A D C E$ (рис. 2) при протіканні рідини через систему.

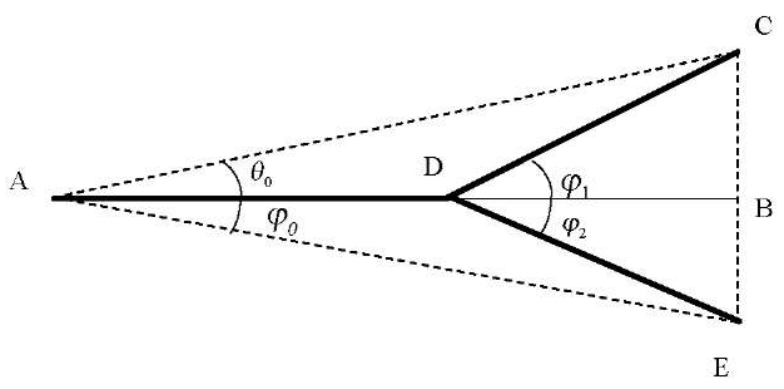

Puc. 2. Модель розгалуження судин.

Позначимо довжини ділянок: $\lambda_{t}=|A B|, \lambda_{r}=|D C|$, $\lambda_{E}=|D E|$. Повний опір ділянки $A D C E-R_{T}$, який складається з суми опорів всіх ділянок $R_{V} \lambda_{V}, R_{C} \lambda_{C} R_{E} \lambda_{E}$, запишемо наступним чином:

$$
R_{T}=R_{V} \lambda_{V}+R_{C} \lambda_{C}+R_{E} \lambda_{E}
$$

Згідно з принципом оптимальності, судини, які розгалужуються від основного стовбура, мають біфуркувати в точці В, що мінімізує опір ділянки при протіканні рідини до точок $A$ та Е. Нескладно помітити, 
що залежність опору системи від радіуса має обернений характер: чим менший радіус, тим більший опір. Використаємо елементарні тригонометричні формули для визначення $R_{T}$ через кут $\varphi$ :

$R_{T}=R_{V} \lambda_{0}\left(\operatorname{ctg} \varphi_{0}-\operatorname{ctg} \varphi_{1}\right)+R_{C} \lambda_{0} \operatorname{cosec} \varphi_{1}$

$+R_{E} \lambda_{1} \operatorname{cosec} \varphi_{2}$

Згідно із законом Пуазеля, який описує потік рідини в жорстких трубах, питомий опір жається через відповідні радіуси формулами:

$R_{V}=k r_{0}^{-4}$,

$R_{C}=k r_{1}^{-4}$,

$R_{E}=k r_{2}^{-4}$,

де основний стовбур, ділянка $\mathrm{AB}$, має радіус $r_{0}$ ділянки $D C$ та $D E$ радіуси $r_{1}$ та $r_{2}$ відповідно, $k-$ деякий коефіцієнт пропорційності, який залежить від в'язкості та щільності рідини.

Підставивши ці співвідношення в (1) знаходимо . як функцію кута $\varphi$.

$$
\begin{aligned}
& R_{T}=R_{V}\left(\lambda_{0} \operatorname{ctg} \varphi_{0}-\frac{1}{2} \lambda_{0} \operatorname{ctg} \varphi_{1}-\frac{1}{2} \lambda_{1} \operatorname{ctg} \varphi_{2}\right)+ \\
& +R_{C} \lambda_{0} \operatorname{cosec} \varphi_{1}+R_{E} \lambda_{1} \operatorname{cosec} \varphi_{2} .
\end{aligned}
$$

Для знаходження $\varphi_{1}$ та $\varphi_{2}$, що мінімізують $R_{T} 3$ (3) розв'язуємо наступну систему рівнянь

$$
\left\{\begin{array}{l}
\frac{\partial R_{T}\left(\varphi_{1}, \varphi_{2}\right)}{\partial \varphi_{1}}=0 \\
\frac{\partial R_{T}\left(\varphi_{1}, \varphi_{2}\right)}{\partial \varphi_{2}}=0
\end{array}\right.
$$

3 якої отримуємо оптимальні значення кутів та

Отже, підставимо відповідні елементи рівнянь (2) та (3) в рівняння (4) і отримаємо:

$$
\left\{\begin{array}{l}
\frac{1}{2} k r_{0}^{-4} \lambda_{0} \frac{1}{\sin ^{2} \varphi_{1}}+k r_{1}^{-4} \lambda_{0} \frac{\cos \varphi_{1}}{\sin ^{2} \varphi_{1}}=0 \\
\frac{1}{2} k r_{0}^{-4} \lambda_{0} \frac{1}{\sin ^{2} \varphi_{2}}+k r_{2}^{-4} \lambda_{0} \frac{\cos \varphi_{1}}{\sin ^{2} \varphi_{2}}=0
\end{array}\right.
$$

Спростимо (5) та маємо:

$$
\left\{\begin{array}{l}
\frac{1}{2} r_{0}^{-4}+r_{1}^{-4} \cos \varphi_{1}=0 \\
\frac{1}{2} r_{0}^{-4}+r_{1}^{-4} \cos \varphi_{2}=0
\end{array}\right.
$$

Знайдемо значення кутів $\varphi_{1}$ та $\varphi_{2}$ :

$\left\{\begin{array}{l}\varphi_{1}=\frac{1}{2} \arccos \left(\frac{r_{1}}{r_{0}}\right)^{4} \\ \varphi_{2}=\frac{1}{2} \arccos \left(\frac{r_{2}}{r_{0}}\right)^{4}\end{array}\right.$

Чисельний експеримент. Запропоновану модель (7) ми перевіряли, використовуючи числові значення діаметрів судин та кутів їх розгалуження, наведені в роботі [16]. Порівнювалися кути розгалуження артерій та вен різних тканин (двоголового, квадратного м'язів, головного мозку, брижі щурів при житті та після смерті) для нормотензивних та спонтанно гіпертензивних щурів. Для судин діаметром від 10 мкм до 100 мкм коефіцієнт кореляції для $\varphi_{1}$ та $\varphi_{2}$ в основному був більший 0,93, що свідчить про адекватність запропонованої моделі.

Для порівняння також використали формули (8) подані в [1]: Коефіцієнт кореляції був приблизно на тому ж рівні.

$\cos \theta=\frac{r_{0}^{4}+r_{1}^{4}-\left(r_{0}^{3}-r_{1}^{3}\right)^{\frac{4}{3}}}{2 r_{0}^{2} r_{1}^{2}}$,

$\cos \varphi=\frac{r_{0}^{4}+r_{2}^{4}-\left(r_{0}^{3}-r_{2}^{3}\right)^{\frac{4}{3}}}{2 r_{0}^{2} r_{2}^{2}}$

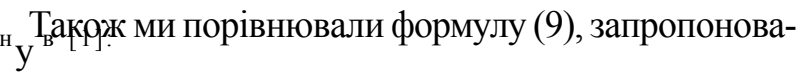

$\theta_{\text {min }}=\arccos \left(\frac{r_{1}^{4}}{r_{0}^{4}}\right)$

В даному випадку при розрахунку кута розгалуження середнє значення коефіцієнта кореляції було в межах 0,7 .

Висновок. 1. В роботі проведено огляд в галузі оптимальності судинної архітектоніки. Запропоновано модель біфуркацій судин та перевірено ії на існуючих результатах дослідження.

2. Отримані нами значення $\varphi_{1}$ та $\varphi_{2}$ корелювали зі значеннями, отриманими експериментально, коефіцієнт кореляції був більший 0,93, що свідчить про прийнятність запропонованої моделі.

3. Запропоноване для розрахунку кутів розгалуження судин діаметром від 10 мкм до 100 мкм співвідношення (7) є прийнятнішим та підтверджує правило Ру, використане в моделі Мюррея [6]. 


\section{Література}

1. Розен Р. Принцип оптимальности в биологии : пер. с англ. / В. М. Волосова. - М. : Мир, 1969. - 215 с.

2. Архитектоника кровеносного русла / К. А. Шошенко, А. С. Голубь, В. И. Брод [и др.]. - Новосибирск: Наука, 1982. - 183 с.

3. Глотов В. А. Структурный анализ микрососудистых бифуркаций (микрососудистый узел и гемодинамический фактор) : автореф. дис. на соиск. научн. степени д. мед. наук : спец. 14.00.02. "Анатомия человека" / В. А. Глотов; Смолен. госуд. мед. акад. - Санкт-Петербург, - 1998. - 23 с. 4. Куприянов В. В. Организация микроциркуляторного сосудистого русла и некоторые вопросы гемодинамики / В. В. Куприянов, В. И. Козлов // Вестник АМН СССР. - 1971. - №> 11. - C. 56-67.

5. Roux W. Uber die Verzweichungen der Blutgefässe / W. Roux. //Z. Naturwissenschaft. - 1878. - Bd. 12. - P. 205-266.

6. Rosen R. Optimality Principles in Biology / R. Rosen London: Butterworth \& Co. Ltd. 1967. - xii + 198 pp., illus.

7. Thompson D'Arcy W. On growth and form / D'Arcy W. Thompson. - New York, Macmillan: Cambridge University Press, 1942. $-1116 \mathrm{p}$.

8. Murray C. D. The physiological principle of minimum work / C. D. Murray // The vascular system and the cost of blood volume I.. Proc. Natl.Acad. Sci. - 1926. - №> 12. - P. 207-214.

9. Мамисашвили В. А. Критерий оптимального функционирования подсистем крупных и мелких пиальных артерий / В. А. Мамисашвили, М. К. Бабунашвили, Г. И. Мчедлишвили // Физиол. журн. - 1975. - Т. 61, №> 10. - С. 1501-1506.
10. Barfred M. Bifurcation analysis of nephron pressure and flow regulation / M. Barfred, E. Mosekilde, N.-H. HolsteinRathlou // Chaos. - 1996. - Vol. 6. - P. 280-287.

11. Marsh D. J. Nonlinear interactions in renal blood flow regulation / D. J. Marsh, O. V Sosnovtseva, K. H. Chon, N.-H. Holstein-Rathlou // Amer. J. Physiol. - 2005. - Vol. 288. P. 1143-1159.

12. Jensen K. S. Selfsustained oscillations and chaotic behavior in kidney pressure regulation / K. S. Jensen, E. Mosekilde, N.-H. Holstein-Rathlou // Mondes Develop. - 1986. - Vol. 55. - P. 91-109.

13. Holstein-Rathlou N.-H. A dynamic modelof the tubuloglomerular feedback echanism / N.-H. Holstein-Rathlou, D. J. Marsh // Amer. J. Physiol. - 1990. - Vol. 258. - P. 14481459.

14. Magnitude of TGF-initiated nephron-nephron interactions is increased in SHR / Chen Yu-Ming, Kay-Pong Yip, D.J. Marsh, N.-H. Holstein-Rathlou // Amer. J. Physiol. - 1995. - Vol. 269. P. 198-204.

15. Postnov D. E. Cooperative phase dynamics in coupled nephrons / D. E. Postnov, O. V. Sosnovtseva, E. Mosekilde, N.-H. Holstein-Rathlou // Intern. J. Mod. Phys. B. 2001. Vol. 15. - Р. 3079-3098.

16. Брод В. И. Особенности пространственной организации кровеносного русла у спонтанно гипертензивных крыс : дис. на соискание научной степени кандидата биол. наук: 03.00.13 / Брод Вера Ильинична. - Н., 1986. - 189 с. 